\title{
On Text Coherence via Frame-Based Presuppositions
}

\author{
Hranush Tovmasyan \\ Yerevan Brusov State University of Languages and Social Sciences
}

\begin{abstract}
The article is an attempt to shed light on one of the most interesting issues on the crossroads of psycholinguistics, pragmatics and cognitive linguistics - framebased semantics and frame-based presuppositions as text coherence means. The findings of the article allow of the following statement: the text is implicitly bound via complex mental structures - frames - by virtue of their hierarchic, presuppositional structure. The appearance of a frame in the context implicitly introduces pieces of information - presuppositions - from its information slots. The presuppositions structured in the slots of the frame create predictable associations of words and word-combinations on the surface structure of the text, thus securing its coherence.
\end{abstract}

Key words: frame, frame-based presuppositions, text coherence, linguistic picture of the world, presupposition base, consciousness, speaking individual.

\section{Introduction}

With the rise of pragmatics, psycholinguistics, cognitive linguistics and ethnolinguistics there have appeared such notions as the presupposition, frame, precedent phenomenon, cognitive structure, and many others which disclose the actual functioning of human thinking activity and its linguistic output - text - via patterned background knowledge. A variety of the latter is the frame which I will minutely elaborate in the present paper and try to prove the hypothesis that frames are in fact presuppositional structures, that's to say units of the presupposition base of the speaking individual, as well as that they implicitly contribute to the coherence of the text and structure its context.

I find it timely to define the notion of the speaking individual, proceeding from the scientific data based on previous research (Karaulov 1982; Johnstone 1996). It is noteworthy that initially the term linguistic individual appeared in linguistic literature before it was introduced into the sphere of scientific terminology by $\mathrm{Yu}$. Karaulov (1982). This idea was further developed in the work of B. Johnstone (1996). Both scholars view the linguistic individual as a human being who is 
endowed with the potential of learning a language and who masters it in the process of his/her socialization. Hence, in my understanding the linguistic individual is in fact the language speaker. I term it the speaking individual as the speech counterpart of its language variant - linguistic individual.

As for presupposition base (notion and term proposed by me) it is the bulk of knowledge and ideas which are first reflected and then shaped as such in a human being's consciousness as a result of the cognitive, speculative process which starts at his/her birth and develops throughout life.

The notion of the presupposition base is crucial in this paper as frames are actually units of it. Another key characteristic of the frame is that due to its cognitive, presuppositional content it acts as context coherence and text cohesion means. These are the key points I will dwell upon in this article.

Thus, in the present paper I will dwell upon the notion of the frame in general and my own perception of it, aiming to prove its presuppositional nature and, hence, text coherence function.

\section{The Presuppositional Nature of the Frame}

I endorse the view of the frame as an anthropological, cognitive, social and cultural phenomenon. Within this perspective I consider that a human being's mental picture of the world is anthropological, culturally and cognitively marked which means that our mental images impose on us certain culturally based concepts and codes of behavior and conduct. Thus, the speaking individual's mental picture of the world has the imprint of the given nation and culture. In this respect, upholding A. Wierzbicka, E. Paducheva states Meaning is anthropological, that is to say it reflects the human nature, further, it is ethnocentric which means it is directed at the ethnos. It is impossible to describe the world by the given language "as it is" - the language a prori imposes a certain picture of the world on its speakers, moreover, each language its own (Vezhbitskaya 1996:5-6). Thus, the mental picture of the world is not neutral from the man and his/her linguo-culture.

Knowledge and ideas are preserved in human consciousness via cognitive structures. The world, regardless of the national and cultural belonging of the man, is the same. The later comes to prove that the consciousness of any human being must contain certain shared, universal information structures. This standpoint is definitely true, otherwise it would be impossible to communicate for people with different cultural backgrounds. Thus, there are certain primitives of shared information that is common for everyone. In this respect it is relevant to quote A. 
Wierzbicka, [...] effective communication between different cultures straightforwardly depends on semantic primitives - identity of the majority of predominant semes, from which each language can create practically an endless list of culturally-based notions (configuring the primitives in different ways). The integrity of such shared primitives can account for "the psychic unity of mankind" (Boas 1938) and the hypothesis that the lexis of different languages embodies different configurations of the common set, would explain the peculiarities in language and thinking typical to different cultures. [...] there is a set of semantic primes that coincide with the set of lexical universals, and the integrity of those universals lies in the basis of human communication and thinking, further in different languages the unique configurations of the primes reflects the diversity of cultures (Vezhbitskaya 1996:296-297). Thus, A. Wierzbicka made a successful attempt to discover the concepts that exist as words in each of the world's languages, semantic primitives, or semantic primes or lexical universals. Based upon an extensive collection of empirical linguistic data, A. Wierzbicka has derived a working list of semantic primitives. As J. Hoyt said in his article Finding Meaning in Meaning, published in the Periphery Journal in 2012, Wierzbicka's work suggests that these semantic primitives are universal among the world's languages, which is to say that certain meanings are universal among humans [...]. It could be that all natural languages, despite the diversity among languages, share the same set of basic meanings because such meanings are innate in humans - we might be born knowing the meanings of semantic primes. Or, it could be that all natural languages share the same set of basic meanings because the humans that speak those languages have an innate propensity to lexicalize the same set of concepts - we might be born meaning to know the world through words. Either way, though A. Wierzbicka likely would subscribe to the latter possibility, her research into semantic primitives unquestionably means a whole lot to meaning (Hoyt 2012:23). The above-said makes it clear that meaning is anthropological and culturally-born.

Thus, the difference lies in the configuration of the universal mental images knowledge and ideas - which undoubtedly has cognitive nature. The latter means that each language, depending on the culture it serves, stipulates its own unique configurations of the mental images which are reflected in human consciousness as more complex mental units than cognitive structures and precedent phenomena (precedent phenomena are experience-based mental unites of human consciousness that contain presuppositions as its semantic blocs). In my account these culturally- 
and cognitively-based complex mental structures are frames which are composed of a kernel surrounded by information units. Note that these information units are the basically culturally-based aspect of the frame. Saying basically, I restate the above-mentioned view that any frame contains a portion of information that is universal which is met in homonymous frames of different cultures. These are actually the semantic premes proposed by A. Wierzbicka. It is noteworthy that communication - text composition and its adequate comprehension - would be impossible if frames contained only culturally-based phenomena. The frame incorporates the universal and the special, imparting a unique configuration to them. Thus, the frame contains two types of information - universal, non-cultural and culturally marked information, presuppositions on a certain topic. The latter becomes evident at the surface structure of the text - via its lexical cohesion.

In research literature there is a multitude of more or less identical definitions given to the notion of the frame with slight divergences though (Minskiy 1979; Naisser 1981; Kulakov 1979; Vshivkova 1987; Fillmore 1992; Gorokhova 1985; Abelson 1977; Cook 1994; Schank 1977; Bellezza 1982; Bower 1979; Charniak 1978; Lehnert 1980; Johnson-Laird 1983; Stilling 1987; Carberry 1990; Fiske \& Taylor 1991; Eyesenck 1993; Wilensky 1994; van Dijk 1997; Berger \& Bradac 1982 and others).

My perception of the frame is most identical with M. Minsky's standpoint which describes the fame as a cognitive structure in a man's phenomenological domain based on the awareness of standard situations and certain expectations deriving from that awareness - what features and relations should a real or imaginary object have. Structurally the frame is composed of a peak (topic), that is, a macroproposition and slots or terminals which are filled with propositions. This cognitive structure is organized around a certain concept, though contrary to an empty set of associations, such units contain only most essential, typical and potential information associated with that concept (Makarov 1998:19).

It is noteworthy that the frame has had a variety of names ascribed to it, the idea underlying it being the same though - scenario (Sanford \& Garrod 1998), frame (Minskiy 1979), script (Schank, Abelson 1977). The difference lies in the fact that as a rule the frame refers to fixed structures (for example, the pattern of elections) while scenario to the dynamic ones (for example, procedure of holding elections). As a unity of the two T. van Dijk proposes the term situation pattern. His elaborate argumentation on the topic is presented in Epizodicheskiye modeli $v$ obrabotke diskursa (van Deyk 2000:9) which is based on the importance of the basic role of the 
patterns in social cognition. In fact, situation patterns are forms of presenting one's self experience. The idea of the pattern is correlated to the individual experience of real or imaginary situations in regard to how texts should be generated and comprehended. Discourse gives a general idea of a certain part of the world which I term situation. The pattern is the cognitive correlate of the situation - it is what happens in a human being's consciousness when he/she faces a certain situation. Hence, the pattern contains individual knowledge that one can have about similar situations, that knowledge - presuppositions - is the result of previous experience accumulated though encountering such situations. New knowledge about such situations contributes to the amplification and development of the pattern. In this perspective T. van Dijk claims that if mental structures contain knowledge about stereotypical situations, then situation patterns contain speakers' individual knowledge (van Deyk 2000:68-69).

Let us elaborate and argument on the above-said. In fact a human being does not reflect the world through separate images as knowledge and ideas but rather via some complex structural units - frames which are thematic blocs. Each frame contains one macroproposition, that is, the semantic kernel that creates that frame. Information is accumulated in the frame around the kernel. The information must be closely related to the topic of the kernel. In this perspective I would like to introduce some correctives in the definition of the frame upholding V. Krasnykh (1999), that is, the information accumulated around the kernel is predictable for the given culture. According to V. Cherneyko and L. Dolinsky (1996:33) semantic associations in human consciousness are spontaneous and that there does not exist and cannot be invariant associative links (Leontyev 1961; Tarasov 1985 and others). Nonetheless, it should be mentioned that the associations are the already existing spontaneous associative links of deep structures preserved in human consciousness. Thus, howsoever spontaneous the associations are, they are predictable. The predictability is due to deep semantic units - frames - existing in human consciousness. The frame is a thematic structure and can be figuratively described as beeswax whose cells are filled with knowledge and ideas connected with its topic. The close study of frames allows of the finding that the frame is a more complex presuppositional structure and a form of structural organization of the presupposition base. Consequently, the mental reflection of the world in human consciousness is a priori pre-organized. Each reflected unit which must turn into knowledge or an idea and further a presupposition, from the first stage of its reflection process enters different frames due to its associative links. 
To make the above-state more tangible let us consider the frame wedding in the Armenian culture. Note that the semantic kernel, that is, the notion of wedding, is the same with all cultures - two people who have decided to bond their lives together by way of marriage. Yet, in every culture it is realized differently, turning into a mental image in human consciousness, then a frame as a semantic kernel with its culturally based knowledge - presuppositions. Thus, the frame wedding will be different from language to language, that is, the data, presuppositions associated with it are different. For example, if someone asks an average representative of the Armenian culture to describe Armenian wedding - its frame actually - he/she will say a great wedding ceremony, luxurious white bridal dress to symbolize purity, gold rings, zurna and dhol (national Armenian musical instruments), breaking plates on the threshold of the house, spreading lavash (Armenian national thin bread) over the shoulders of the newlyweds, honey-tasting treated by the future mother-in-law, solemn oath in front of the altar, the newlyweds unbind two white pigeons in the churchyard after the sacred ceremony, godfather, godmother, mothers-in-law, fathers-in-law, wedding reception, toastmaster, wedding cake, barbecue, bouquet throwing by the bride, the first night, the red apple (the symbol of virginity in the Armenian culture), honeymoon, etc. The frame wedding of a representative of another culture will not contain half of the mentioned items, while there will be others missing in the Armenian frame wedding. For example, in Indian and other cultures, besides the bouquet throwing, there is a tradition to throw the bride's garter to the assembled unmarried men; the man who catches it is supposedly the next to wed, etc.

A frame, in my understanding, is a predictable store of information about a certain phenomenon. It is a set of presuppositions available in that frame. And once the addresser introduces the word wedding in the text, moreover when both the addresser and the addressee are Armenian, he/she contributes the whole predictable frame knowledge - presuppositions - on wedding to the context which will display a predictable set of words and their associations on the surface structure of the text. Consequently, the surface structure of the text is also predictable - the network of the chosen words, their associations as they are in fact the linguistic carriers of the frame data. Language actualizes the contents of the speaking individual's consciousness as a picture of the world. Appearing in a certain thematic domain, the speaking individual a priori structures the surface structure of his/her text which is indeed first shaped in its deep structure, that is, discourse context.

Indeed, speaking about a wedding in any other culture will yield a text whose surface structure - word choice and its associations - is completely different from 
the Armenian one, for example. The latter largely depends on the frame and its semantic, presuppositional slots.

Note that the frame is a larger mental unit than the precedent phenomenon which is due to the fact that the frame makes different predictable associations and by this includes one or more precedent phenomena. To prove all above-stated I have carried out a small quiz among my acquaintances on the topic Armenian wedding which is in fact the frame I elaborate. Besides the above-given language units, created by associations, most of the respondents gave other associations as well, they are as follows: ¿uin hujquilui hupuminp (the so called fat Armenian wedding, that is, a pompous wedding with a lot of guests and traditional Armenian wedding realia. In this particular case it is the name of the TV program),

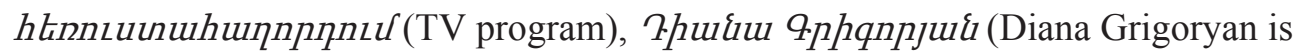
a famous Armenian actress, TV presenter and script writer), qJnıququi hupuukippitip (rural weddings which preserve the flavor and the colouring of traditional Armenian weddings), etc. Obviously, the frame Armenian wedding (indeed, for each Armenian based on his/her own experience) contains a precedent phenomenon - the 2uin hujluuluk hupuukhp program aired on Armenia TV which in its turn is composed of other precedent phenomena - series of the TV program as well as the precedent name Diana Grigoryan. Thus, the structure of the frame stipulates predictable associative links and relations between the component presuppositions of that frame which actually predict their potential appearance in the text.

There is another example in store which also displays the multilevel hierarchic structure and predictable associations of the frame. The latter is also an outcome of the quiz. I asked Armenians of different age and social backgrounds to speak on the notion of tale. There came up the following spontaneous associations

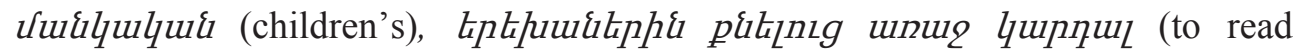

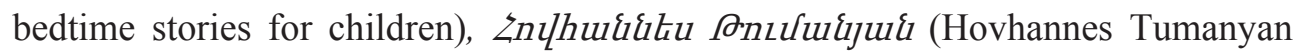
was an outstanding Armenian poet, writer, tale-teller, translator, literary and public activist. He is considered to be the national poet of Armenia), Uh quphl UtinpL (A drop of honey - the name of the famous Armenian tale by H. Tumanyan), Cnulis nu quinnzis (The dog and the cat - the name of the famous Armenian tale

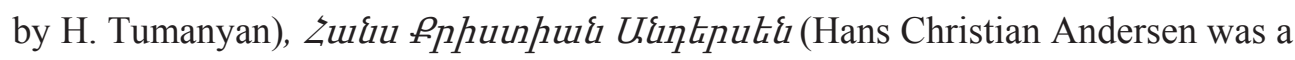
Danish author. Although a prolific writer of plays, travelogues, novels, and poems, Andersen is best remembered for his fairy tales), etc. as well as such utterances as 
Llphump tu uuundnul (You are telling a tale! - used to mean that someone is making up stories), Zliphuplitp uh' шuиnuhp (Don't tell tales! - especially used

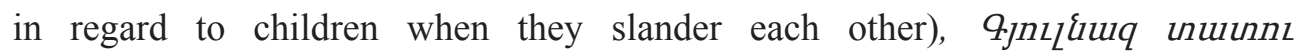
hliphuplitp (old wife's tales, urban legends). Undoubtedly, the given entities refer to the kernel tale but they go in different directions - to real tales that are precedent texts, to tale writers who are precedent names and to national folk sayings which are precedent texts. The analyzed examples expose both the complex hierarchic structure and the marked cultural, national nature of the frame. The latter accounts for its predictable associations.

Research on the frame proves there can be all-cultural frames, though it is impossible to state to the full that they are really all-cultural as there will always be entities unknown to a representative of some other culture. For example, Colosseum which is considered a universally renowned cultural monument will indeed call forth a multilevel frame in the consciousness of most people, though it does not stand for its being all-cultural which actually proves that the frame is an outcome of a nation's routine and culture. Besides, each nation, each culture perceives universal phenomena due to different configurations of these phenomena in their consciousness. Due to this in research literature there have appeared such terms as culturally valued frame and imaginary gestalt structures (Teliya 1996). The given notions are analyzed only in the framework of language and culture if nominative units (like the Russian samovar, or perestroika) have cultural memory but can point at a certain culturally valued frame due to their own meanings and encyclopedic base (Teliya 1996:82-83). In this perspective V. Teliya furthers that, The fact that culture "is incorporated" in language is unquestionable - language as a means of communication accumulates in meanings all that is connected with the cultural-traditional competence of its representatives, which passes from generation to generation by virtue of the language (Teliya 1996:84-85). It is timely to quite B. Worf's (1940:97) standpoint here regarding how language influences the formation of the mental picture of the world in human consciousness, how a human being processes information, stores it in his/her memory and reproduces it. In this perspective there come up a number of questions - how language signs appear, why there are so many nominations of types of snow in the Eskimo language while in other languages there are not, why there are so many nominations of cars in all languages but in Lappish there are so few or almost none. Most probably it is accounted for by the fact that the more a certain experience is important for us, the more elaborate are language means to verbalize them. The 
language is not merely a means of expressing human thoughts, it is rather a means of verbalizing a certain picture of the world organized in human consciousness via frames - sophisticated presuppositional structures. Hence, the development of certain language codes depends on cultural needs; when members of a certain language group assimilate them, they simultaneously assimilate essential cultural values, too (Soslo 1997:361).

In this respect let us consider an excerpt from Cockles Mussels:

A gang of men and girls came stepping out in arrow, arms linked, breasting the whole width of the road, and singing, and for a second Miss Parson was caught up among them, she could see the white teeth and peacock-painted eyes of the girls, smell the men's sweat, and they parted and went on like the tide, leaving her behind.

(Hill 1978:294)

The thematic directive of the given multi-predicative structure is stipulated by the topic of its first part which actually shapes its frame careless youth, which makes part of a larger frame youth as its sub-frame. The subsequent parts of the multipredicative structure develop and back up the topic. The author chooses such words and word combinations from the frame careless youth that reflect the hierarchic structure of the frame as well as such youth-characteristic actions which are stereotypical and derive from the frame. By this, the author creates a chain of nominal units that must embody and reflect the frame in the text. The pre-positive segment A gang of men and girls came stepping out in arrow predetermines the above-stated topic and thus the choice of the frame. The following predicative segment contains stereotypical actions, presuppositions arms linked; breasting the whole width of the road; singing; went on like the tide generating from the frame. The next fragment white teeth and peacock-painted eyes of the girls, men's sweat contains words and word-combinations denoting a careless lifestyle and characteristics peculiar to the careless youth. The semantic components presuppositions - of the sub-frame careless youth passes through the whole text via well-chosen and structured surface structure means.

Indeed, some nominative units chosen by the author straightforwardly connect with the topic of the frame, its stereotypical kernel, as for example arms linked, white teeth, peacock-painted eyes of the girls, smell the men's sweat, singing, though there are also such ones that are somehow far from the prototypical meaning of the frame, 
yet, a close examinations will disclose that they are also associated with that prototype. For example, came stepping out in arrow, breasting the whole width of the road, and went on like the tide.

Thus, this fragment of the text is shaped according to the repeated meaning of the frame careless youth which is portrayed by such words that belong to one semantic domain - frame. The peak of the frame is the component that maximally reflects the features characteristic of other units of the same group (Givon 1986:195).

Obviously, the composition of the text is accompanied by the joint projection of the two types of cognitive structures - phenomenological and linguistic. By their nature both structures are presuppositional as they contain some knowledge - extralinguistic or linguistic. Phenomenological structures make part of frames, while the linguistic ones verbalize these deep semantic structures. In this perspective it is relevant to quote S. Ter-Minasova (2000) who gives her account of how cultural frames influence the collocability of lexical means. She claims that different word combinations are used to denote the same notion in different languages. For example, in Russian it is said высокая трава (tall grass) while the English say long grass. Isn't this accounted for by the English tradition according to which the grass must always be trimmed as hair, moustache and beard, while in the Russian tradition grass is an element of nature, it grows itself as trees and bushes. All this is stipulated by the mental cultural structures frames.

An overview of the study reveals that frames are subjective phenomena. The situation can be described by the text and its compositional units. By this the speakers of the language express their vision, interpretation of the world, which give ground to assume that these means are not arbitrary - they reflect the main categories and the structure of our cognition of the world. That is, before initiating a talk on a certain topic the language speaker creates an inner speech in his mind. The inner speech carries the whole cognitive load of the language speaker, reflected in the presupposition base, which is expressed in outer speech by such surface structures that immediately reflect the associations and relations of the units of the inner speech.

\section{Conclusion}

To round off the discussion of frame-based presuppositions in the perspective of text cohesion means it should be said that the mechanism responsible for the work of the human consciousness is the presupposition base. The presupposition 
base is the mental picture of the world - composed of knowledge and images which is shaped and developed throughout the whole life of a speaking individual. The presupposition base is actually an information pool, set of presuppositions. The data stored in the presupposition base - the knowledge and images about the world - are actually presuppositions preserved in human consciousness via cognitive structures. The cognitive structures - presuppositions - are organized in the presupposition base as unities of more complex and hierarchic type. These unities are frames composed of a macroproposition and a network of culturally marked, associated presuppositions. This feature of the frame creates predictable semantic links. By their structure frames are more complex phenomena than the cognitive structures. Hence, one cognitive structure contains one presupposition on some phenomenon of the world or of the language. Frame is a complex notion composed of a large number of semantically interwoven cognitive structures - presuppositions. The appearance of the frame in the text calls forth a set of the presuppositions from its structure, thus implicitly securing its coherence.

\section{References:}

1. Bellezza, F.S.; Bower, G.H. (1982) Remembering Scripts-Based Texts II. // Poetics. Vol. 11, № 1, pp. 1-23.

2. Berger, C.R.; Bradac, J. (1982) Language and Social Knowledge. London: Academic Press.

3. Boas, F. (1911) The Handbook of North American Indians. Vol. I, Washington, DC: Smithsonian Institution. Available at: http://biblio.wdfiles.com/local-files/boas-1911-introduction/boas_1911_introduction.pdf [Accessed November 2016].

4. Boas, F. (1938) The Mind of Primitive Man. New York: The Free Press.

5. Bower, G.H.; Black, J.B.; Turner, T.J. (1979) Scripts in Memory for Texts II. // Cognitive Psychology. Vol. 11. pp. 177-220, Cambridge: CUP.

6. Carberry, S. (1990) Plan Recognition in Natural Language Dialogue. Cambridge, Mass.: MIT Press.

7. Charniak, E. (1978) On the Use of Framed Knowledge in Language Comprehension II. // Artificial Intelligence. Vol. 2 (3). pp. 225-265.

8. Cherneiko, L.O.; Dolinskiy, V.A. (1996) Imya SUD'BA kak ob 'yekt kontseptual'nogo i assotsiativnogo analiza. // Vestnik MGU. Seriya 9. Filologiya. N 6. S. 20-41.

9. Cook, G. (1994) Discourse and Literature. Oxford: OUP. 
10. Deyk, van T.A. (2000) Yazyk. Poznanie. Kommunikatsiya. Blagoveschensk: BGK (Blagoveschenskiy gumanitarniy kolledzh). // N.A. Boduena de Kurtene.

11. Dijk, T.A. van (1997) Discourse as Social Interaction. London: Sage.

12. Eyesenck, M.W. (1993) Principles of Cognitive Psychology. Hove, UK: Psychology Press.

13. Fillmore, C.J.; Atkins, B.T. (1992) Towards a Frame-Based Lexicon: The Semantics of RISK and Its Neighbors. // Frames, Fields, and Contrasts: New Essays in Semantics and Lexical Organization / Ed. by A. Lehrer \& E. Kittay, pp. 75-102. Hillsdale NJ: Lawrence Erlbaum.

14. Fiske, S.T.; Taylor, S. (1991) Social Cognition. NY: McGraw-Hill.

15. Givon, T. (1986) Prototypes: Between Plato and Wittgenstein II. // Noun Classes and Categorization. / Proceedings of a Symposium on categorization and noun classification, Eugene, Oregon, October 1983 I. / Ed. by C. Craig. Amsterdam, Philadelphia, pp. 77-102.

16. Gorokhova, S.I. (1985) Freim-podkhod $k$ opisaniyu protsessa porozhdeniya rechi.//Rechevoe obschenie: tseli, motivy, sredstva. M.: Institut yazykoznaniya AN SSSR, s. 89-102.

17. Hill, S. (1978) Cockles Mussels. // Interpretatsiya teksta, V.A. Kukharenko, M.: Prosvescheniye.

18. Hoyt, J. (2012) Finding Meaning in Meaning. // Periphery Journal. Available at: $<$ http://www.lu.lv/fileadmin/user_upload/lu_portal/apgads/PDF/Book_Valodu _centrs_kopaa_gatavs.pdf $>$ [Accessed November 2016].

19. Johnson-Laird, P. (1983) Mental Models: Towards a Cognitive Science of Language, Inference, and Consciousness. Cambridge: CUP.

20. Johnstone, B. (1996) The Linguistic Individual: Self-Expression in Language and Linguistics. Oxford: OUP. Available at: <https://books.google.am/ books?id=2oczxBLIrsgC\&pg=PA140\&lpg=PA140\&dq=SPEAKING+individ ual,+LINGUISTICS\& source=bl\&ots=oZW5Dp2BIW\&sig=IJcWMRisHHrhv pHQNcMx7DE j60\&hl=hy\&sa=X\&ved=0CFIQ6AEwB2oVChMI7PPVquq CxwIVwtssCh1AVwDr\#v=onepage\&q=SPEAKING\%20individual\%2C\%20 LINGUISTICS\&f $=$ false $\geq$ [Accessed November 2016].

21. Karaulov, Yu. (1982) Rol' pretsedentnykh tekstov v strukture i funktsionirovanii yazykovoy lichnosti. // VI Mezdunarodniy kongress MAPRYaL. Sovremennoe sostoyanie i osnovy problemy izucheniya i prepodavaniya russkogo yazyka i literatury. Doklady sovetskoy delegatsii. M.: Russkiy yazyk.

22. Krasnykh, V.V. (1999) "Maski" $i$ "roli" freim-struktur soznaniya (k voprosu o klishe $i$ shtampakh soznaniya, etalony $i$ kanony). // Yazyk, soznanie, kom- 
munikatsiya: Sbornik statey. / Ed. by V.V. Krasnykh, A.I. Izotov. M.: Dialog - MGU, Vyp. 8. S. 39-43.

23. Kulakov, F.M. (1979) Prilozhenie k russkomu izdaniyu. // Minskiy M. Freimy dlya predstavleniya znaniy.: perevod s angl. M. Minskiy. M.: Energiya, s. 122144.

24. Lehnert, W.G (1980) The Role of Scripts in Understanding.//Frame Conceptions and Texts Understanding. Berlin, NY: De Gruyter. pp. 75-95.

25. Leontyev, A.N. (1961) Chelovek i kul'tura. M.: Politizdat.

26. Makarov, M.L. (1998) Interpretativniy analiz diskursa v maloy gruppe. Tver: Izdatelstvo Tverskogo gosudarstvennogo universiteta.

27. Minskiy, M. (1979) Freimy dlya predstavleniya znaniy. M.: Energiya.

28. Naisser, U. (1981) Poznanie i realnost. M.: Progress.

29. Sanford, A.J.; Garrod, S.C. (1998) The Role of Scenario Mapping in Text Comprehension. // Discourse Processes, 26 (2-3), pp. 159-190.

30. Schank, R.C.; Abelson, R.P. (1977) Scripts, Plans, Goals and Understanding: An Inquiry into Human Knowledge Structures. Hillsdale, N.J.: L. Erlbaum Associates.

31. Sokuler, E.A. (1997) Sub'yekt, soznanie, "drugie soznaniya”; nekotorye interpretatsii filosofii L. Vitgenshteina. // Sovremennaya analiticheskaya filosofiya. Vyp. 3. Soznanie i deistvitelnost: Sbornik obzorov. // INION AN SSSR. R. Soslo. Kognitivnaya psikhologiya. M.: Griviola.

32. Stilling, N.A.; Feinstein, M.H.; Garfield, J.L. et al. (1987) Cognitive Science: An Introduction. London, Cambridge, Mass.: MIT Press.

33. Tarasov, E.F. (1985) Metodologicheskie problemy issledovaniya rechevogo obscheniya. // Rechevoe obschenie: tseli, tomivy, sredstva. M.: AN SSSR, Institut yazykoznaniya, s. 4-10.

34. Tarasov, E.F. (1997) Nekotorye poznavatel'nye problemy, analiz soznaniya. / XII Mezhdunarodnyi simpozium po psikholingvistike i teorii kommunikatsii. Moskva, 2-4 iyunya. M., s. 149.

35. Teliya, V.N. (1996) Rol obraznykh sredstv yazyka $v$ kulturno-natsionalnoy okraske miroponimaniya. // Etnolingvisticheskiye aspekty prepodavaniya inostrannykh yazykov. M.: Nauka, s. 82-89.

36. Ter-Minasova, S.G. (2000) Yazyk $i$ mezhkulturnaya kommunikatsiya. M.: Slovo.

37. Vezhbitskaya, A. (1996) Yazyk. Kul'tura. Poznanie. M.: Russkie Slovari.

38. Vshivkova, T.V. (1987) Protsess antitsipatsii i ponimanie teksta. // Semantika 
tselogo teksta. M.: Prosveschenie.

39. Whorf, B. (1940) Language, Thought and Reality: Selected Writings of Benjamin Lee Whorf . J. / Ed. by Caroll. Cambridge, MA: MIT Press.

40. Wierzbicka, A. (1972) Semantic Primitives. Frankfurt: Athendum.

41. Wilensky, R. (1994) Discourse, Probability, and Inference. // Beliefs, Reasoning, and Decision Making. Hillsdale, pp. 363-388.

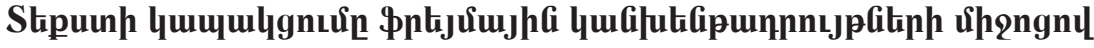

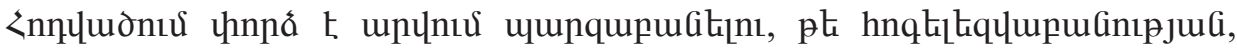

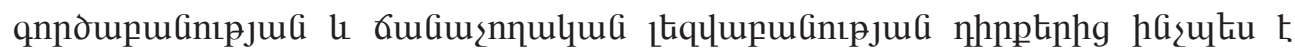

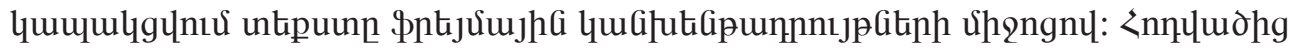

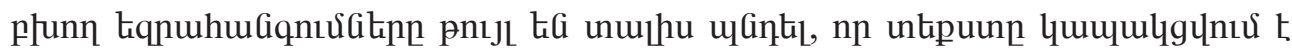

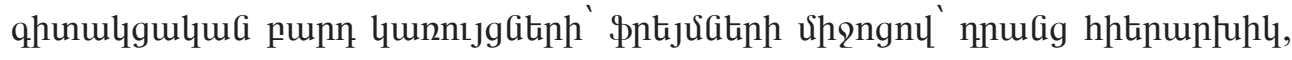

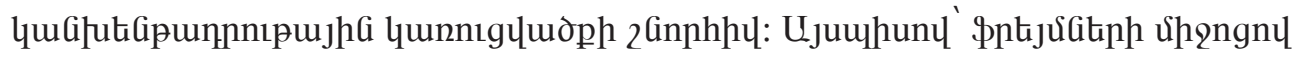

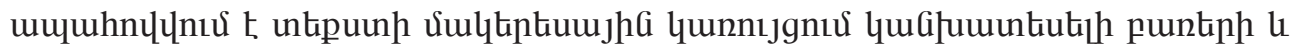

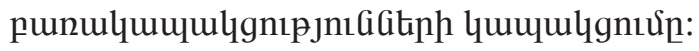

